\title{
Sustainability in Oceans Governance: Small Islands, Emerging Powers, and Connecting Regions
}

\author{
Joris Larik \\ The Hague Institute for Global Justice and Leiden University \\ Abhijit Singh \\ The Observer Research Foundation
}

\begin{abstract}
As evidenced by Goal No. 14 of the UN's Sustainable Development Goals, the importance of oceans governance as a matter of global policy can hardly be overstated. The unsustainable uses of their resources could lead to serious consequences, not only for coastal communities, but remote landlocked countries as well. This special section aims to take the international community's clarion call for effective norms, institutions, and multi-stakeholder cooperation back to the oceans through three topical case studies. Each in its own way illustrates humanity's high stakes in blue growth, offering recommendations on how states and governments must craft coherent, effective, and actionable policies to make sustainable oceans governance a reality. Claire van der Geest's article opens the special section with a focus on the Indian Ocean and the need to redesign its fisheries governance. Hongzhou Zhang and Fengshi Wu subsequently investigate two of the most significant structural shifts of China's marine fisheries sector in the past decades, namely, going outward and focusing on high market value species. James Malcolm concludes the special section by switching attention to small island developing states, arguing that sustainable oceans governance for them represents not 'only' an environmental or economic concern, but indeed a matter of national security.
\end{abstract}

The importance of sustainable oceans governance as a matter of global policy can hardly be overstated. According to the United Nations Food and Agricultural Organization (FAO), 17 per cent of animal protein in humanity's diets is produced by fisheries and aquaculture, supporting 'the livelihoods of some 12 percent of the world's population' (FAO, 2016). Moreover, estimates by the World Bank indicate that approximately 350 million jobs are linked to the oceans through fishing, aquaculture, coastal and marine tourism and other oceans-related activities, while many rapidly growing coastal cities rely on desalinated seawater for their freshwater supply (World Bank, 2014). Meanwhile, an 'estimated 40 percent of the carbon in the atmosphere that becomes bound in natural systems is cycled into the oceans and wetlands' (FAO, 2016). These are only some illustrations of the key role oceans play is nurturing life. The unsustainable uses of their resources could lead to serious consequences, not only for coastal communities, but remote landlocked countries as well. ${ }^{1}$

In 2012, delegates at the Rio+20 Conference recognized the need for a marine complement to 'green growth', as efforts intensified to shift the green model towards a 'blue economy' framework (United Nations, 2012). Three years later, in September 2015, the role of oceans as an integral part of the sustainable development agenda was recognized in the Sustainable Developments Goals (SDGs). Regarding Goal No. 14 - 'Conserve and sustainably use the oceans, seas and marine resources for sustainable development' the 2016 progress report reiterates that oceans, 'along with coastal and marine resources, play an essential role in human well-being and social and economic development worldwide', including the regulation of 'the global ecosystem by absorbing heat and carbon dioxide from the atmosphere' (United Nations Economic and Social Council, 2016).

Sustainable oceans governance has become a global mandate, the fulfillment of which will require action and reform at different levels of governance and include the participation of a wide range of stakeholders. The SDGs recognize that the multiple objectives concern diverse substantive areas, which cannot be achieved without wellfunctioning governance mechanisms and a global multistakeholder partnership. Accordingly, Goal No. 16 calls for 'effective, accountable and inclusive institutions at all levels', while with a view to SDG No. 17, which calls for a 'Global Partnership for Sustainable Development', realization of 'the ambitious targets of the 2030 Agenda requires a revitalized and enhanced global partnership that brings together Governments, civil society, the private sector, the United Nations system and other actors and mobilizes all 
available resources' (United Nations Economic and Social Council, 2016, para 117).

This special section aims to take the clarion call for effective norms, institutions and multi-stakeholder cooperation back to the oceans through three topical case studies. Each in its own way illustrates humanity's high stakes in blue growth, offering recommendations on how states and governments must craft coherent, effective, and actionable policies to make sustainable oceans governance a reality.

These reflections and recommendations come at a crucial time. On the one hand, global governance at large is faltering, with doubts being cast on the benefits and desirability of globalization and multilateralism in a changing geopolitical environment. Cooperation in economic and environmental matters is no exception to this trend, as the fate of major trade agreements such as the Trans-Pacific Partnership (TPP) and the Transatlantic Trade and Investment Partnership (TTIP), each with its own dedicated chapter on sustainable development, hangs in the balance - as does the fate of the 2016 landmark Paris Climate Agreement.

On the other hand, high-level discussions on improving oceans governance continue, with the next milestone being the High-Level UN Conference to Support the Implementation of SDG No. 14 in New York, also known as the UN Ocean Conference. However, sustainable oceans governance will not be achieved through summitry, but on the ground through continuous improvements at multiple levels, including in big and small economies - particularly the gravely affected small island development states (SIDS).

With this timing and these considerations in mind, the special section contains a set of articles, each of which delves deeper into the challenges presented by contemporary oceans governance. The section brings together a selection of updated and revised contributions from a pool of eminent experts at the international workshop on 'Global Oceans Governance' at The Hague Institute for Global Justice in April 2016. ${ }^{2}$

Claire van der Geest opens the special section with a focus on the Indian Ocean and the need to redesign its fisheries governance. Due to poor regional governance arrangements, even the existence of two regional fisheries management organizations cannot overcome deficiencies in effectively managing these resources in a sustainable way in accordance with relevant international legal obligations. Taking as the starting point the above-mentioned SDG No. 14, van der Geest highlights the imperative to implement performance-based management arrangements for fisheries in the Indian Ocean.

This will not be possible without a revamping of regional governance arrangements. This includes closing gaps and remedying deficiencies while giving effect to existing obligations and enabling management decisions that consider new and emerging issues, in particular climate change. Van der Geest draws on examples and best practices from other theaters, while taking into account the specific circumstances of the Indian Ocean and its high number of developing coastal states. To policymakers, van der Geest addresses two options for reform: a more ambitious path, which includes the establishment of a new overarching treaty creating a single platform for ocean-wide scientific and monitoring, control and surveillance (MCS) support; and, as a more politically feasible option in the mid-term, the establishment of a new ocean-wide treaty for the provision of scientific and MCS services for the high seas with an opt-in clause for coastal state exclusive economic zones (EEZs) combined with amendments to the existing instruments to address current gaps.

Hongzhou Zhang and Fengshi Wu put the spotlight on China and its marine fisheries policy. To policymakers and the general public, China is, of course, well-known as a global economic powerhouse and an increasingly important governance actor. However, the immensity of the Chinese fishing industry and the significance of its policies for sustainable oceans governance, is only starting to be fully appreciated. Zhang and Wu investigate two of the most significant structural shifts of China's marine fisheries sector in the past decades, that is, going outward and focusing on high market value species. The article explains how the trajectory of China's marine fisheries sector has been shaped by the country's emerging policies. The authors explore options for transnational advocacy and analyze the potential for external agencies to introduce changes in China's practices to revert some of the ongoing trends and improve the sustainability of its fishery practices. Their reform proposals stress on the need for a multi-stakeholder approach, accounting for the views of NGOs, expert networks and other forms of non-confrontational transnational policy advocacy.

James Malcolm concludes the special section by switching attention to small island developing states, arguing that sustainable oceans governance for them represents not 'only' an environmental or economic concern, but indeed a matter of national security. Malcolm's article shows that maritime security challenges are publicly communicated by SIDS with the aim of elucidating the context within which security policy and practice emerge. The main research question, the article emphasises, is the conceptualization of maritime security by SIDS actors to include elements of sustainable development. It does so by focusing on the negotiation and content of key UN conference documents and SIDS input. The author argues that the SIDS' conceptualization of maritime security is inextricably linked to concerns about sustainable development, going also well beyond climate change. The article calls for more research on SIDS' conceptualization of maritime security, including regional variations, and recommends to SIDS policymakers the development of holistic sustainable blue growth strategies to bring multiple stakeholders together. Most importantly, the SIDS' perception of maritime security is influenced by their ability to emphasize vulnerability, as also the opportunities associated with their maritime domain.

The articles in this section underscore the need for 'special attention' to the Oceans. In this, the emphasis must be on better oceans governance at the national, regional and international levels, involving all relevant stakeholders, and working towards tangible improvements. The stakes for blue 
growth remain as high as ever - for regional states, local communities, as well as the representatives of the international community at the 2017 UN Ocean Summit and well beyond.

\section{Notes}

The editors wish to thank the anonymous reviewers for their helpful feedback on the draft articles contained in this special section as well as the research assistants from Leiden University College The Hague - Laurie Morgan, Monica Sanchez Groeneweg, Frenkchris Sinay and Eirin Sundby - for their hard work and valuable support.

1. For a comprehensive assessment of unsustainable practices, see the report by the Global Ocean Commission (2014).

2. The conference was organized by The Hague Institute for Global Justice and the Observer Research Foundation, with support from the Ministry of Foreign Affairs of the Netherlands and Leiden University. The conference featured four thematic panels addressing issues of maritime ecology in the age of climate change, the maritime dimension of sustainable development under the UN's 2030 Agenda, threats to maritime security, and holistic approaches to maritime security and governance.

\section{References}

Food and Agricultural Organization (FAO) (2016) The State of World Fisheries and Aquaculture 2016: Contributing to food security and nutrition for all, Rome, 81 [online]. Available from: http://www.fao. org/3/a-i5555e.pdf [Accessed 8 February 2017].

Global Ocean Commission (2014) From Decline to Recovery: A Rescue Package for the Global Ocean (Oxford 2014) [online]. Available from: http://www.some.ox.ac.uk/wp-content/uploads/2016/03/GOC_report_ 2015.July_2.pdf [Accessed 8 February 2017].

United Nations (2012) Report of the United Nations Conference on Sustainable Development, Rio de Janeiro, Brazil, 20-22 June 2012, A/ CONF.216/16 (New York 2012), 68.

United Nations Economic and Social Council (2016) Progress towards the Sustainable Development Goals, Report of the Secretary-General, 3 June 2016, E/2016/75, para 95.

World Bank (2014) The Living Oceans, 12 April 2014 [online]. Available from: http://go.worldbank.org/A2MYFIUQM0 [Accessed 29 January 2017].

\section{Author Information}

Joris Larik is Senior Researcher at The Hague Institute for Global Justice and Assistant Professor at Leiden University. His work focuses on the role of regional organizations in international law and politics and global governance reform. Larik is the author of Foreign Policy Objectives in European Constitutional Law (2016) and winner of the 2008 NATO Manfred Wörner Essay Award.

Abhijit Singh is Senior Fellow and Head of the Maritime Policy Initiative at the Observer Research Foundation (ORF) in New Delhi. A former Indian naval officer, he has edited two books on maritime security Indian Ocean Challenges: a Quest for Cooperative Solutions (2013) and Geopolitics of the Indo-Pacific (2014), and has also written extensively on Indian Ocean governance issues. 